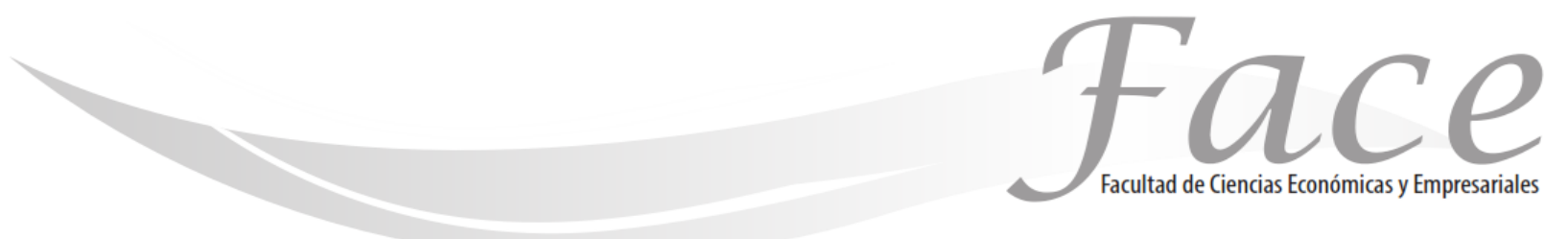

ISSN Impreso: 1794-9920

ISSN Electrónico: 2500-9338

Volumen 21-N¹

Año 2021

Págs. 125 - 135

(cc) (†) (ㅇ)

\title{
ANÁLISIS DE LAS CONDICIONES DE SALUD Y SEGURIDAD EN EL TRABAJO EN LA PLAZA DE MERCADO DE UBATÉ Y ZIPAQUIRÁ
}

Fecha de Recepción: Noviembre 7 de 2020

Fecha de Aprobación: Febrero 10 de 2021

Gina Fuentes Rojas *
$\frac{\text { https://orcid.org/0000-0002-9314-6070 }}{\text { Diana Rincón Téllez ** }}$
$\frac{\text { https://orcid.org/0000-0002-7247-7073 }}{\text { Ever Fuentes Rojas *** }}$
$\frac{\text { https://orcid.org/0000-0003-4698-2268 }}{\text { Carlos Lozano Piedrahita }{ }^{* * *}}$

\section{Resumen:}

La seguridad y salud en el trabajo en la informalidad es una responsabilidad individual y colectiva cuyo eje central es priorizar acciones que permitan mitigar la presencia de enfermedades laborales en los diferentes contextos organizacionales. El objetivo de la presente investigación es identificar la relación existente entre las condiciones de seguridad y salud en el trabajo y la presencia de sintomatología asociada a las actividades laborales en los trabajadores informales de la plaza de mercado de Ubaté y Zipaquirá. Se realiza un estudio cuantitativo, de corte transversal con alcance correlacional, en el que se diseña un instrumento de recolección de datos tipo cuestionario. La población fue de 377 puestos de mercado en Ubaté y 389 en Zipaquirá; mediante un muestreo aleatorio simple (MAS) para poblaciones finitas, se determinó el tamaño de la muestra, 183 y 151 puestos de trabajo para las plazas de mercado de Ubaté y Zipaquirá respectivamente. Se determina la prevalencia de sintomatología asociada a las condiciones de salud como el dolor de cabeza, la presencia de condiciones que garanticen la seguridad en el trabajo de acuerdo a la percepción del entrevistado, un bajo porcentaje de afiliación al régimen contributivo de salud, de cotización a pensión y afiliación a la administradora de riesgos labores (ARL). Con un 95\% de confianza, se encontró asociación ( $p=0,001)$ entre las variables horas de trabajo y presencia de sintomatología asociada a su estado de salud en las dos Plazas de mercado, sugiriendo así la importancia de implementar medidas de control e intervención que permitan mejorar las condiciones de los trabajadores.

Palabras clave: condiciones de seguridad, informalidad, trabajo, Condiciones de Salud..

\footnotetext{
* Docente de la Corporación Universitaria Minuto de Dios - UNIMINUTO, Facultad de Administración, Programa de Administración en Seguridad y Salud en el Trabajo. Cra 15 No 1-22, Zipaquirá, Cundinamarca, Colombia. Contacto: gfuentesroj@uniminuto.edu.co

** Universidad Libre de Colombia, Facultad de Ingeniería, Programa de Ingeniería Industrial. Bogotá, Cundinamarca, Colombia. Contacto: ever.fuentes@unilibre.edu.co
}

"*t Universidad Nacional de Colombia, Facultad de Ingeniería, Programa de Ingeniería Industrial. Bogotá, Cundinamarca, Colombia. Contacto: cjlozanop@unal.edu.co 


\title{
ANALYSIS OF HEALTH AND SAFETY CONDITIONS AT WORK IN THE MARKET SQUARE OF UBATÉ AND ZIPAQUIRÁ
}

\begin{abstract}
:
Health and safety at work in informality is an individual and collective responsibility whose central axis is to prioritize actions that allow mitigating the presence of occupational diseases in different organizational contexts. The objective of this research is to identify the relationship between health and safety conditions at work and the presence of symptoms associated with work activities in informal workers in the market place of Ubaté and Zipaquirá. A quantitative, cross-sectional study with correlational scope is carried out, in which a questionnaire-type data collection instrument is designed. The population was 377 market stalls in Ubaté and 389 in Zipaquirá; Through simple random sampling (SRS) for finite populations, the sample size was determined, 183 and 151 jobs for the market places of Ubaté and Zipaquirá respectively. The prevalence of symptoms associated with health conditions such as headache, the presence of conditions that guarantee safety at work according to the perception of the interviewee, a low percentage of affiliation to the contributory health scheme, of contributions is determined. to pension and affiliation to Occupational Risk Manager (ORM) With 95\% confidence, an association ( $p=0.001$ ) was found between the variables hours of work and the presence of symptoms associated with their health status in the two market places, thus suggesting the importance of implementing control and intervention measures that allow to improve the conditions of the workers.
\end{abstract}

Keywords: Safety conditions, informality, work, health conditions.

\section{ANÁLISE DAS CONDIÇÕES DE SAÚDE E SEGURANÇA NO TRABALHO NA PRAÇA DE MERCADO DE UBATÉ E ZIPAQUIRÁ:}

A saúde e segurança no trabalho na informalidade é uma responsabilidade individual e coletiva cujo eixo central é priorizar ações que permitam mitigar a presença de doenças ocupacionais em diferentes contextos organizacionais. 0 objetivo desta pesquisa é identificar a relação entre as condições de saúde e segurança no trabalho e a presença de sintomas associados à atividade laboral em trabalhadores informais do mercado de Ubaté e Zipaquirá. É realizado um estudo quantitativo, transversal, de abrangência correlacional, no qual é elaborado um instrumento de coleta de dados do tipo questionário. A população era de 377 bancas em Ubaté e 389 em Zipaquirá; Por meio de amostragem aleatória simples (SRS) para populações finitas, foi determinado o tamanho da amostra, 183 e 151 empregos para os mercados de Ubaté e Zipaquirá respectivamente. É determinada a prevalência de sintomas associados a condições de saúde como cefaleia, presença de condições que garantem a segurança no trabalho na percepção do entrevistado, baixo percentual de afiliação ao regime contributivo de saúde, de contribuições. à previdência e afiliação a Occupational Risk Manager (ORM) Com 95\% de confiança, foi encontrada associação $(p=0,001)$ entre as variáveis jornada de trabalho e a presença de sintomas associados ao seu estado de saúde nos dois mercados, sugerindo que importância de implementar medidas de controle e intervenção que permitam melhorar as condições dos trabalhadores.

Palavras-chave: Condições de segurança, informalidade, trabalho, condições de saúde. 


\section{INTRODUCTION:}

Informality is a condition that has increased year after year, generating economic opportunities and at the same time lack of labor protection, this situation has generated an increase in the accident rate and incidence of occupational disease, impacting the economic development of the countries (García, Riaño and Benavides, 2012).

A relevant aspect lies in the increase in people in a condition of informality. According to DANE (2021), the population of informal workers is $48.1 \%$ of the population in the main cities and metropolitan areas; For Nuñez (2002) this situation is associated with tax evasion and payment of social benefits, without considering the implication that this situation can generate in this population.

The phenomenon of informality occurs worldwide, causing people to decide to continue in a permanent job offer, where the lack of opportunities in companies in the formal sector, causes this type of work to increase exponentially, and the lack of controls and interventions in the face of existing dangers and risks remains latent, thus being a risk to society. (Jaramillo et all, 2015). In this order of ideas, it is relevant to bring up the three types of informality proposed by Fernández, Villar, Gómez, and Vaca (2017). The first called voluntary informality, there is the decision to be informal, since they consider that the benefits are greater; The second is Induced Informality, where despite having the willingness to get a formal job and be productive, labor barriers relegate them, evidencing discrimination and the third is Mixed Informality, in which there are unproductive workers, with preference for informality.

These three types of informality allow a greater number of people to remain in these groups, generating income to satisfy basic daily needs, including their family nucleus.
The issue of Safety and Health at Work in the informal sector has been approached as a pillar at the level of different entities such as the International Labor Organization (ILO) and the World Health Organization (WHO). Current regulations require that hazard identification and risk assessment be implemented in order to carry out controls according to the labor needs of workers; However, with the informal population the phenomenon is different, since the resources that ensure the occupational health and safety management system are not allocated, and the interest in joining the entities that guarantee social security, this is how the risks and dangers, the lack of knowledge on the subject and the lack of controls in this population generate a permanent risk in the development of the activities of informal workers

The International Labor Organization - ILO states the following: the incidence of informality is one of the most persistent, negative and worrying characteristics of the labor markets in Latin America and the Caribbean. Just over half of the 263 million workers in the region work in the informal sector, that is, about 140 million workers. (ILO, 2018, p. 15).

In this way, the ILO (2018) makes it clear that informality involves working personnel who are outside the system or government policies of each country and therefore, are outside the scope of formality and what it represents; They are people who do not have affiliation to the social security system, therefore, they are not covered by labor legislation, they are not part of the welfare state, nor of the social pact that should characterize modern societies (p. 15).

Based on the above, it is evident that in the municipalities of Ubaté and Zipaquirá informal work is permanent in different economic activities; These are carried out in rural or urban areas, in the commercialization of goods and in the provision of services, both in the public zone and in established areas; In this way, the exposure of workers to different risks is observed, which are projected in the possible 
presence of diseases and the tendency to suffer accidents that lead to negative and permanent consequences.

Based on the above, we seek to answer the following research question. ¿What are the health and safety conditions at work in the market square of Ubaté and Zipaquirá?

\section{METODOLOGY}

The methodology of the research carried out responds to a cross-sectional, quantitative study with correlational scope, (Hernández et all 2015) in order to identify the relationship between health and safety conditions at work and the presence of symptoms associated with work activities in informal workers of the market square of Ubaté and Zipaquirá.

The study population corresponds to 389 and 377 jobs in the market places of the municipality of Zipaquirá and Ubaté respectively; The sample was estimated through simple random sampling (SRS) for finite populations, through the following equation:

$$
\mathrm{n}=\mathrm{Z}_{\propto}^{2} \frac{\mathrm{N} \times \mathrm{p} \times \mathrm{q}}{\mathrm{i}^{2}(\mathrm{~N}-1)+\mathrm{Z}_{\propto}^{2} \times \mathrm{p} \times \mathrm{q}}
$$

It was determined that the sampling frame with a confidence level of $95 \%$ and an estimation error of $5.2 \%$, for the Ubaté market place corresponds to 183 jobs; and with a confidence level of $95 \%$ and an estimation error of $6.25 \%$, for the Zipaquirá market place there is a minimum of 151 jobs, for a total of 334 surveys applied.

The considerations for the definition of the sample space were: the person had to be a worker at one or more market stalls, voluntary consent, as well as the consent of the administration of the market place.

The technique used to collect the information was the survey, for which a questionnaire was designed as an instrument consisting of qualitative and quantitative categorical and numerical variables with nominal (dichotomous and polytomous), ordinal and interval scales. This instrument was evaluated by 5 expert judgments, who made the contributions for its validation.

The variables analyzed are affiliation to the social security system, symptoms presented by the surveyed workers, safety conditions, hours and time at work in the activity; This database was systematized using the Microsoft Excel program and later, it was imported into the SPSS version 26.0 program for the description of the sociodemographic and occupational variables and for the association between the variables with the chi $^{2}$ test to compare the association between the conditions. of safety and health at work and symptoms presented in their state of health

\section{RESULTS:}

Table 1 shows the distribution of participation in the study, of the 334 workers, $54.8 \%$ (183) work in the market place of Ubaté and $45.2 \%$ (151) in the market place of Zipaquirá. Distributed by gender, it is evident that the female gender prevails with $68.2 \%$ (228). 
Table 1. Gender distribution by market place

\begin{tabular}{lllll}
\hline Marketplace & \multicolumn{2}{c}{ Male } & \multicolumn{2}{c}{ Feminine } \\
\cline { 2 - 5 } & $\mathrm{n}$ & $\%$ & $\mathrm{n}$ & $\%$ \\
Ubaté & 44 & 13,2 & 139 & 41,6 \\
Zipaquirá & 62 & 18,6 & 89 & 26,6 \\
\hline
\end{tabular}

\section{Source: Authors}

The mean (standard deviation) of age of the workers in the Ubaté market place is category $3(0.9)$, therefore, they are in an age range between 31 to 50 years, while the workers of the Zipaquirá market square have an average age range between 51 to 65 years (4).

Table 2. Age, time of work in the activity and average hours of work per day

\begin{tabular}{|c|c|c|c|c|c|c|}
\hline \multirow{2}{*}{$\begin{array}{l}\text { CENTRAL } \\
\text { TREND AND } \\
\text { DISPERSION } \\
\text { MEASURES }\end{array}$} & \multicolumn{2}{|c|}{ Age (Years) } & \multicolumn{2}{|c|}{$\begin{array}{l}\text { Work time in } \\
\text { the activity }\end{array}$} & \multicolumn{2}{|c|}{$\begin{array}{c}\text { Average } \\
\text { working } \\
\text { hours per } \\
\text { day }\end{array}$} \\
\hline & $\begin{array}{l}\text { Uba } \\
\text { té }\end{array}$ & $\begin{array}{l}\text { Zipa } \\
\text { quirá }\end{array}$ & Ubaté & $\begin{array}{l}\text { Zipaqu } \\
\text { irá }\end{array}$ & $\begin{array}{l}\text { Uba } \\
\text { té }\end{array}$ & $\begin{array}{l}\text { Zipaqu } \\
\text { irá }\end{array}$ \\
\hline Mean & 3 & 4 & 4 & 4 & 3 & 3 \\
\hline Median & 3 & 4 & 5 & 5 & 3 & 4 \\
\hline Mode & 3 & 4 & 5 & 5 & 3 & 4 \\
\hline Dev. Deviation & 0,9 & 0,8 & 1,2 & 1,1 & 0,6 & 0,8 \\
\hline Variance & 0,8 & 0,7 & 1,4 & 1,2 & 0,3 & 0,6 \\
\hline
\end{tabular}

\section{Source: Authors}

Regarding the working time in the activity and the average hours of work per day, in both market places it is observed that the average is the same, that is, it corresponds to category 4 , assigned to the interval of 6 to 10 years for the case of the variable working time and for the variable average hour's category 3 , assigned to the interval from 4 to 6 hours.

Table 3 shows the mode in the category of affiliation to the social security system, in which four (4) variables are analyzed; In this way, it is defined that the data that is most repeated in health affiliation is the subsidized regime (2), in pension affiliations and ARL it is not being affiliated (2) and in the type of affiliation, the condition of beneficiary (2)

Table 3. Mode: affiliation to the social security system

\begin{tabular}{ccccc}
\hline Municipality & $\begin{array}{c}\text { Health } \\
\text { affiliation }\end{array}$ & $\begin{array}{c}\text { Pension } \\
\text { affiliation }\end{array}$ & $\begin{array}{c}\text { ORM } \\
\text { affiliation }\end{array}$ & $\begin{array}{c}\text { Type of } \\
\text { affiliation }\end{array}$
\end{tabular}

\begin{tabular}{lllll}
\hline Ubaté & 2 & 2 & 2 & 2 \\
Zipaquirá & 2 & 2 & 2 & 2
\end{tabular}

\section{Source: Authors}

Only $19.2 \%$ of the workers are affiliated to the contributory health regime, $9.0 \%$ contribute for pensions and only $5.7 \%$ are affiliated to the Occupational Risk Manager (ORM)

In the same way, it is observed that $30.5 \%$ are in the quality of affiliated with health as contributors.

Comparing the results of affiliation to the Social Security system, a higher percentage is evidenced in affiliation to the contributory health regime in the market place of the municipality of Zipaquirá $(20.5 \%)$, the same behavior is observed for affiliations to pension and ORM 
ISSN: 1794-9920 Impreso / Electrónico 2500-9338

Enero - Junio. Volumen 21 Número 1, Año 2021 Págs. 125-135

Table 4. Affiliation to the social security System

\begin{tabular}{|c|c|c|c|c|}
\hline \multirow{3}{*}{$\begin{array}{c}\text { VARIABLE } \\
\text { HEALTH MEMBERSHIP }\end{array}$} & \multicolumn{4}{|c|}{ Marketplace } \\
\hline & \multicolumn{2}{|c|}{ Ubaté } & \multicolumn{2}{|c|}{ Zipaquirá } \\
\hline & $\mathrm{n}$ & $\%$ & $\mathrm{n}$ & $\%$ \\
\hline Contributory regime & 33 & 18,0 & 31 & 20,5 \\
\hline Subsidized regime & 148 & 80,9 & 115 & 76,2 \\
\hline None & 1 & 0,5 & 4 & 2,6 \\
\hline Does not respond & 1 & 0,5 & 1 & 0,7 \\
\hline PENSION MEMBERSHIP & $\mathrm{n}$ & $\%$ & $\mathrm{n}$ & $\%$ \\
\hline Yes & 7 & 3,8 & 23 & 15,2 \\
\hline Do Not & 176 & 96,2 & 120 & 79,5 \\
\hline Does not respond & 0 & 0,0 & 8 & 5,3 \\
\hline ORM AFFILIATION & $\mathbf{n}$ & $\%$ & $\mathrm{n}$ & $\%$ \\
\hline Yes & 5 & 2,7 & 14 & 9,3 \\
\hline Do Not & 178 & 97,3 & 130 & 86,1 \\
\hline Does not respond & 0 & 0,0 & 7 & 4,6 \\
\hline TYPE OF MEMBERSHIP & $n$ & $\%$ & $\mathrm{n}$ & $\%$ \\
\hline Contributing & 55 & 30,1 & 47 & 31,1 \\
\hline Beneficiary & 128 & 69,9 & 102 & 67,5 \\
\hline Does not respond & 0 & 0,0 & 2 & 1,3 \\
\hline
\end{tabular}

\section{Source: Authors}

An interesting aspect lies in the absence of affiliation to a social security system, thus being $69.9 \%$ of the beneficiary population, which represents the absence of coverage in the event of an occupational accident or illness.
Table 5. Symptoms of workers

\begin{tabular}{|c|c|c|c|}
\hline VARIABLE & Category & $n$ & $\%$ \\
\hline \multirow{3}{*}{ Headache } & Yes & 156 & 46,7 \\
\hline & & & \\
\hline & Do not & 178 & 53,3 \\
\hline \multirow{3}{*}{ Neck Pain } & Yes & 105 & 31,4 \\
\hline & & & \\
\hline & Do not & 229 & 68,6 \\
\hline \multirow{3}{*}{ Arms pain } & Yes & 146 & 43,7 \\
\hline & & & \\
\hline & Do not & 188 & 56,3 \\
\hline \multirow{3}{*}{ Hand pain } & Yes & 131 & 39,2 \\
\hline & & & \\
\hline & Do not & 203 & 60,8 \\
\hline \multirow{3}{*}{ Numbness in Hands } & Yes & 95 & 28,4 \\
\hline & & & \\
\hline & Do not & 239 & 71,6 \\
\hline \multirow{3}{*}{ Back pain } & Yes & 139 & 41,6 \\
\hline & & & \\
\hline & Do not & 195 & 58,4 \\
\hline \multirow{3}{*}{ Leg pain } & Yes & 124 & 37,1 \\
\hline & & & \\
\hline & Do not & 210 & 62,9 \\
\hline \multirow{3}{*}{ Leg numbness } & Yes & 72 & 21,6 \\
\hline & & & \\
\hline & Do not & 262 & 78,4 \\
\hline \multirow{2}{*}{ Frequent cough } & Yes & 39 & 11,7 \\
\hline & Do not & 295 & 88,3 \\
\hline \multirow{3}{*}{ Frequent flu } & Yes & 70 & 21,0 \\
\hline & & & \\
\hline & Do not & 264 & 79,0 \\
\hline \multirow{3}{*}{ Allergies } & Yes & 46 & 13,8 \\
\hline & & & \\
\hline & Do not & 288 & 86,2 \\
\hline \multirow{3}{*}{ Stomach ache } & Yes & 40 & 12,0 \\
\hline & & & \\
\hline & Do not & 294 & 88,0 \\
\hline \multirow{3}{*}{ Sadness feelings } & Yes & 73 & 21,9 \\
\hline & & & \\
\hline & Do not & 261 & 78,1 \\
\hline
\end{tabular}

\section{Source: Authors}


ANÁLISIS DE LAS CONDICIONES DE SALUD Y SEGURIDAD EN EL TRABAJO EN LA PLAZA DE MERCADO DE UBATÉ Y ZIPAQUIRÁ

Gina Fuentes Rojas - Diana Rincón Téllez - Ever Fuentes Rojas -Carlos Lozano Piedrahita

Sadness

$\begin{array}{lllll}\text { feelings } \quad 0,219 & 0,781 & 0,023 & 0,175 & 0,263\end{array}$

The symptoms presented by each of the market place workers were generalized, taking into account each of the following variables: headache, neck pain, arm pain, hand pain, hand numbness, back pain, leg pain, leg numbness, frequent cough, frequent flu, allergies, stomach pain and feelings of sadness. These variables are qualitative, nominal dichotomous; In this way, the $95 \%$ confidence interval is taken as a statistical test to study the prevalence of the variables mentioned above.

Table 6. Confidence intervals for the prevalence of symptoms in workers

\begin{tabular}{|c|c|c|c|c|c|}
\hline \multirow{2}{*}{ VARIABLE } & \multirow{2}{*}{$\begin{array}{c}\text { Prevalence } \\
\text { p }\end{array}$} & \multirow{2}{*}{$\begin{array}{c}1- \\
\text { prevalence } \\
\text { q }\end{array}$} & \multirow{2}{*}{$\begin{array}{l}\text { Stándard } \\
\text { error }\end{array}$} & \multicolumn{2}{|c|}{$\begin{array}{l}\text { Confidence } \\
\text { Interval }\end{array}$} \\
\hline & & & & $\begin{array}{c}\text { minimum } \\
\text { limit }\end{array}$ & $\begin{array}{c}\text { maximum } \\
\text { limit }\end{array}$ \\
\hline Headache & 0,467 & 0,533 & 0,027 & 0,413 & 0,521 \\
\hline Neck Pain & 0,314 & 0,686 & 0,025 & 0,264 & 0,364 \\
\hline Arms pain & 0,437 & 0,563 & 0,027 & 0,384 & 0,490 \\
\hline Hand pain & 0,392 & 0,608 & 0,027 & 0,340 & 0,444 \\
\hline $\begin{array}{l}\text { Numbness } \\
\text { in Hands }\end{array}$ & 0,284 & 0,716 & 0,025 & 0,236 & 0,332 \\
\hline Back pain & 0,416 & 0,584 & 0,027 & 0,363 & 0,469 \\
\hline Leg pain & 0,371 & 0,629 & 0,026 & 0,319 & 0,423 \\
\hline $\begin{array}{c}\text { Leg } \\
\text { numbness }\end{array}$ & 0,216 & 0,784 & 0,023 & 0,172 & 0,260 \\
\hline $\begin{array}{c}\text { Frequent } \\
\text { cough }\end{array}$ & 0,117 & 0,883 & 0,018 & 0,083 & 0,151 \\
\hline Frequent flu & 0,210 & 0,790 & 0,022 & 0,166 & 0,254 \\
\hline Allergies & 0,138 & 0,862 & 0,019 & 0,101 & 0,175 \\
\hline $\begin{array}{c}\text { Stomach } \\
\text { ache }\end{array}$ & 0,120 & 0,880 & 0,018 & 0,085 & 0,155 \\
\hline
\end{tabular}

\section{Source: Authors}

To collect the information in the survey related to safety conditions at work, a Likert-type scale (Wuensch, K. 2015) was used with the following options: never, almost never, sometimes, almost always and always, to questions related to the development of their task; For the purposes of the analysis, each of these variables is converted into a dichotomous variable in such a way that it allows evaluating the absence and presence of safety conditions at work

The 50th percentile or median is determined in the SPSS, which corresponds to a score of 43 ; Therefore, the variables that obtained a score higher than the median are classified with the category absence of safety conditions and those with a lower score with the category of presence of safety conditions at work. The frequency table is constructed separating the results by municipality; In the market place of Ubaté, it is obtained that $28.4 \%$ of the workers surveyed do not present safety conditions in their workplace, unlike the market place of Zipaquirá with a value of $55.6 \%$ compared to it category

Table 7. Confidence intervals for the prevalence of symptoms in workers

Marketplace

VARIABLE

Ubaté Zipaquirá

$\begin{array}{lll} & \\ \mathrm{n} & \% & \mathrm{n}\end{array}$

Lack of safety conditions $\quad 52 \quad 28,4 \quad 84 \quad 55,6$

$\begin{array}{lllll}\text { Presence of safety conditions } \quad 131 \quad 71,6 & 67 & 44,4\end{array}$

Based on the results described above, the $\mathrm{Chi}^{2}$ statistic is applied to analyze the association between variables, which is presented in Table 8 
ISSN: 1794-9920 Impreso / Electrónico 2500-9338

Enero - Junio. Volumen 21 Número 1, Año 2021 Págs. 125-135

Table 8. Chi ${ }^{2}$ test between associated symptoms and Municipality

\begin{tabular}{lcc}
\hline \multicolumn{1}{c}{ Variables Association } & $\begin{array}{c}\text { Pear-son } \\
\text { Chi- } \\
\text { square }\end{array}$ & gl \\
\hline $\begin{array}{l}\text { Health conditions and working } \\
\text { hours }\end{array}$ & 0,000 & 1 \\
$\begin{array}{l}\text { Hours of work and safety } \\
\text { conditions at work }\end{array}$ & 0,001 & 1 \\
Health conditions and Gender & 0,001 & 1 \\
Health conditions and workplace & 0,001 & 1 \\
ORM affiliation AND workplace & 0,001 & 1 \\
$\begin{array}{l}\text { Occupational Conditions and } \\
\text { Workplace }\end{array}$ & 0,001 & 1 \\
\end{tabular}

Source: Authors

It is interesting to observe the association of the variables with a confidence interval of $95 \%, p=0.005$, which occurs in the two workplaces, the market place of Ubaté and Zipaquirá. An association is observed between the variable health conditions and gender, taking into account that the largest informal working population corresponds to the female gender; Similarly, a relationship is observed with the variable hours of work, taking into account that in the two workplaces a number greater than 10 hours of work prevails, a relevant aspect in informal work and in the working conditions that occur. Another interesting variable that presents an association is the workplace (market place) with the variables health conditions and occupational conditions, an aspect that must be evaluated due to the trend of accidents and occupational diseases that may occur. This is how health and safety conditions are homogeneous in the two market places, presenting an interesting association with health conditions

\section{DISCUSSION:}

According to García, Et al. (2012), informality not only impacts on the economic development of countries, but also on public health, and they express in their article "Informality, unemployment and underemployment: a public health problem", when conducting a review of relevant research On the topic of informality, there are studies focused on the evaluation of this labor condition from the economy and politics, however, there is little research focused on the analysis of the working and health conditions in informal sectors, despite the fact that there is evidence of a higher proportion of accidents and illnesses in these workers compared to workers in the formal sector. This is how the association of the variables of health conditions, presence of symptoms such as headache, pain in upper and lower limbs and aspects related to mood and the variable hours of work is evidenced in the present study, which In the informal sector, they are not defined, taking into account that the amount paid is per day worked and not per hours of work, a situation that increases the appearance of symptoms associated with occupational disease

According to Palacios (2011), who argues that informality contributes to creating poverty and social exclusion, often relating health and social security benefits to certain work regulations (p. 598); The study carried out shows that indeed the vast majority of workers are affiliated to the subsidized health system and a small percentage contributes to obtain a pension or is affiliated with an occupational risk insurer (ORM). This situation mentioned by the author is related to the results of this research, where an association of the variable affiliation to the occupational risk insurer and workplace is evidenced; taking into account that in the two market places only a minority is affiliated and is contributing to the ORM, corresponding to $5.7 \%$ of the study sample, thus evidencing a lack of labor protection and greater risks in the presence of accidents or occupational diseases.

The Ministry of Labor, Employment and Social Security et al. (2014) defines working conditions as those factors such as the organization, content and time of work, remuneration, ergonomics, the technology involved, the management of the workforce, social and 
assistance services and, also, worker participation $p$. 13); The evaluation of the risks present in the work environment is deemed convenient to determine the vulnerability of the workers, as well as the level of risk and its influence on health and safety, in order to subsequently generate applicable strategies in accordance with the work Environments.

In Colombia, Law 1562 of 2012 mentions that occupational health and safety are the risks that materialize in occupational accidents and diseases, where it can be defined as a set of variables found in the performance of a task in a environment, determining the health and quality of life of the worker based on the physical, psychological and social state (p.1); In accordance with the above, variables that can generate accidents and occupational diseases were evaluated, which in turn can be confused with diseases of common origin, either due to ignorance or the omission of those requirements that turn an informal population into a formal population or as some authors call it, decent work. This is where the importance of intervening in the market places of the study lies, generating alternatives that allow improving the health and safety conditions at work of informal workers, thus generating a safe work framed in the regulatory characteristics and strict compliance, with main interest according to the results of this study.

Taking into account the WHO (2010), it is important to promote a good work environment that is healthy and critical, since it allows employees and workers to adopt a healthy lifestyle individually; in order to reduce in a certain way the health care costs that the company must pay (p. 18). Hence, the research reflects the need to evaluate working conditions according to the characteristics of the place and the tasks in which the workers perform, under methodologies that allow collecting valid information and where it is possible to mitigate the latent risks that are evidenced in this study, it is important to bear in mind that these risks are related to the tasks of market places and to the health and safety conditions that must prevail in all work environments regardless of the economic sector.

\section{CONCLUSIONS:}

The occupational health and safety component is being handled incipiently in the market places under study and there is evidence of disarticulation throughout the system, generating a wide spectrum of research referring not only to the specific issue of health and safety in the workplace. work, but in administrative, educational, economic, financial and engineering areas.

In the working population of both the market place of Ubaté and Zipaquirá, the absence of symptoms that generate alert in relation to health conditions prevails, however; The association of variables with the chi ${ }^{2}$ test and the confidence interval show a strong association with the long working hours that people present, although it is true when describing only the frequencies the presence of the symptoms is less than the absence of them in workers, but it is an important aspect that must be intervened, taking into account the strong relationship between the variables, it is important to bear in mind that this association can generate a longterm occupational disease and increase the accident rate in informal workers of the market places and in the same way affect their productivity curve.

According to Law 100 of 1993, which created the Social Security System in Colombia, people with an employment relationship are differentiated from people in an informal condition; Within the study, it was found that only $2.4 \%$ (8) of the total sample surveyed (334) comply with the affiliation to the general pension system, the general health social security system and the general occupational risk system, the rest make use of complementary social services.

The Ubaté market place reflects a higher percentage in relation to the presence of safety conditions at work related to characteristics and conditions of the workplace, however, it is found that in both market places there is an association of variables between the health and safety conditions at work, working hours and gender, causing precarious working conditions in informal workers in the market places under study. 
Finally, it can be concluded that it is essential to intervene in the market places, generating public policies that allow improving working conditions and also implementing strategies to mitigate the impact on the health and safety of workers, in such a way that their conditions are improved of health and work, in order that in the long term they become workplaces where safe work is prioritized and safe work opportunities are provided.

This is how it is recommended to carry out studies in which the different methodologies of identification, evaluation and control of hazards and risks are applied.

\section{REFERENCES:}

Colombia. Congreso de Colombia. Ley 100 del 1993; Por la cual se crea el sistema de seguridad, social integral. Diario Oficial No. 41.148 (23 de diciembre de 1993).

Colombia. Congreso de Colombia. Ley 1562 del 2012; Por la cual se modifica el sistema de riesgos laborales y se dictan otras disposiciones en materia de salud ocupacional. Diario Oficial No. 48.488 (11 de julio de 2012).

Departamento Administrativo Nacional de Estadística Colombiano (DANE). (2021). Boletín Técnico Gran Encuesta Integrada de Hogares (GEIH) Octubre - diciembre 2020. https://www.dane.gov.co/files/investigaciones /boletines/ech/ech_informalidad/bol_geih_inf ormalidad_oct20_dic20.pdf (Consultado: 3 de marzo de 2021)

España. Ley 31 de 1995; Prevención de riesgos laborales. B.O.E No. 269 (10 de noviembre de 1995).
Fernández, C., Villar, L., Gómez, N y Vaca, P. (2017) Taxonomía de la informalidad en América Latina. Revista Fedesarrollo, (75). https://www.repository.fedesarrollo.org.co/ha ndle/11445/3476 (Consultado: 7 de marzo de 2020)

Forero, A. y Apolinar, M. (30 de noviembre de 2015). En la zona rural, Colombia se "raja" en trabajo decente. Periódico El Tiempo. https://www.eltiempo.com/archivo/documento /CMS-16445625 (Consultado: 7 de marzo de 2020)

García, J. C., Riaño, M. I., y Benavides, J. A. (2012) Informal employment, unemployment and underemployment: a matter of public health. Revista Salud Pública Informalidad, desempleo y subempleo: Un problema de salud pública. Revista Salud Pública, 14(1), 138-150.

http://www.scielo.org.co/pdf/rsap/v14s1/v14s 1a12.pdf (Consultado: 26 de febrero de 2020)

Ministerio de Trabajo, Empleo y Seguridad Social, Ministerio de Educación, Instituto Nacional de Educación Tecnológica, Organización Internacional del Trabajo. (2014). Salud y seguridad en el trabajo (SST): Aportes para una cultura de la prevención. https://www.ilo.org/wcmsp5/groups/public/@ americas/@ro-lima/@ilobuenos_aires/documents/publication/wcms_ 248685.pdf (Consultado: 13 de agosto de 2020) 
ANÁLISIS DE LAS CONDICIONES DE SALUD Y SEGURIDAD EN EL TRABAJO EN LA PLAZA DE MERCADO DE UBATÉ Y ZIPAQUIRÁ Gina Fuentes Rojas - Diana Rincón Téllez - Ever Fuentes Rojas -Carlos Lozano Piedrahita

Muntaner, C., Benach, J., Chung, H., Edwin, NG., y Schricker, T. (2010). Welfare state, labour market inequalities and health. In a global context: An integrated framework. SESPAS report 2010, Gaceta Sanitaria, 24(S1), 1-128, https://doi.org/10.1016/j.gaceta.2010.09.013 (Consultado: 25 de mayo de 2020)

Núñez, J. A. (2002). Empleo Informal y Evasión fiscal en Colombia. https://colaboracion.dnp.gov.co/CDT/Estudio s\%20Econmicos/210.pdf (Consultado: 26 de febrero de 2020)

Organisation for Economic Cooperation and Development [OECD]. (2018). LATIN AMERICAN AND CARIBBEAN COMPETITION FORUM - Session I: Informal Economy in Latin America and the Caribbean: Implications for Competition Policy. https://one.oecd.org/document/DAF/COMP/L ACF(2018)4/en/pdf (Consultado: 3 de febrero de 2021)

Organización Internacional del Trabajo [OIT]. (2018). Políticas de formalización en América Latina avances $\quad y \quad$ desafios. https://www.ilo.org/wcmsp5/groups/public/--americas/---rolima/documents/publication/wcms_645159.p df (Consultado: 13 de agosto de 2020)

Organización Mundial de la Salud [OMS]. (2010). Entornos Laborales Saludables: Fundamentos y Modelo de la OMS. Wordl Healh Organisation. https://scholar.google.es/scholar?hl=es\&as_s $\mathrm{dt}=0 \% 2 \mathrm{C} 5 \& \mathrm{q}=$ Entornos + Laborales $+\mathrm{Sa}$ ludables $\% 3 \mathrm{~A}+$ Fundamentos+y+Modelo+de+1 $a+O M S \& b t n G=($ Consultado: 2 de febrero de 2020)
Palacios, R. (2011). What does being an "informal worker" mean? Revisions from an athnographic Research Project. Revista Mexicana de Sociología. 73(4). Recovered from:

http://www.scielo.org.mx/scielo.php?script=sc i_arttext\&pid=S0188- (Consultado: 13 de agosto de 2020)

Rahmadani, S., Marhani, Abadi, M.Y., Marzuki, D.S., Sudirman, y Fajrin, M.A. (2020). Analysis of independent National Health Insurance ownership of informal workers: Study of market traders in Gowa District, Indonesia, Enfermería Clínica, 30(6), 295-299, https://doi.org/10.1016/j.enfcli.2020.06.076 (Consultado: 12 de febrero de 2021)

Restrepo, P. (2017). What Is the Informal Labor Market?. Federal Reserve Bank of ST Louis, Central to America's Economy, https://www.stlouisfed.org/on-theeconomy/2017/april/informal-labor-market (Consultado: 12 de febrero de 2021)

Thamrin, Y., Wahyu, A., Russeng, S. S., Wahyunia, A., y Hardianti, A. (2020). Ergonomics and musculoskeletal disorders among seaweed workers in Takalar Regency: A mixed method approach, Medicina Clínica Práctica, 3(S1), https://doi.org/10.1016/j.mcpsp.2020.100110

(Consultado: 23 de noviembre de 2020)

World Health Organization (WHO). (2010). Health Work Environments: WHO Foundation and Model. Contextualization, Practices ans Dupport Literature. Recovered from: https://apps.who.int/iris/bitstream/handle/10665/1 13144/9789241500241_eng.pdf?sequence=1\&is Allowed $=y$ 